$\begin{array}{lr}\begin{array}{l}\text { Australian Journal of } \\ \text { Crop Science }\end{array} & \text { AJCS } \\ \text { AJCS 14(05):857-870 (2020) } & \text { ISSN:1835-2707 }\end{array}$

\title{
Cadmium toxicity and phytoremediation in trees - A review
}

\section{Susana Silva Conceição ${ }^{1}$, Flávio José Rodrigues $\mathrm{Cruz}^{2^{*}}$, Edson Ugulino Lima ${ }^{3}$, Vittorio Ugulino Lima ${ }^{4}$, Jéssica Suellen Silva Teixeira ${ }^{1}$, Diana Jhulia Palheta de Sousa ${ }^{1}$, Tiago Kesajiro Moraes Yakuwa ${ }^{6}$, Antônio Vinícius Correa Barbosa ${ }^{7}$, Cândido Ferreira de Oliveira Neto ${ }^{1}$}

\author{
${ }^{1}$ Universidade Federal Rural da Amazônia, Grupo de Pesquisa Estudos da Biodiversidade de Plantas Superiores, \\ Belém, Pará - Brasil \\ ${ }^{2}$ Universidade Federal Rural de Pernambuco, Programa de Pós-Graduação em Ciência do Solo, Recife, Pernambuco - \\ Brasil \\ ${ }^{3}$ Universidade Federal do Pará - Programa de Pós-Graduação em Diversidade e Agricultura Familiar, Belém, Pará - \\ Brasil \\ ${ }^{4}$ Escola Superior da Amazônia - Centro Universitário do Estado do Pará - CESUPA \\ ${ }^{6}$ Universidade Federal Rural da Amazônia- Programa de Pós-Graduação em Agronomia, Belém, Pará - Brasil \\ ${ }^{7}$ Universidade Federal Rural da Amazônia- Instituto Ciberespacial, Belém, Pará - Brasil
}

*Corresponding author: fjrcpp@outlook.com

Abstract

Over time, the anthropic activity has contributed to alter biogeochemical cycle of heavy metals by releasing contaminants into water, soil and air. Due to contamination of environments with heavy metals, plants and animals consumed by population have presented some level of contamination, which has caused worries and also attempts to minimize these problem. Among heavy metals, cadmium is one of the most toxic to living creatures, occupying seventh position in toxic substances ranking, even with very low concentrations. One of measures adopted to reduce negative impact of soil contamination by heavy metals is phytoremediation. It consists of use of plants that tolerate presence of heavy metals in soil, absorbing, translocating and compartmentalizing them in aerial part, with little or no negative impact on plant growth. Among plants, trees are the most suitable for phytoremediation due to their considerable production of air biomass, which is associated with higher accumulation and consequently higher extraction of heavy metals. In this review, we address main nutritional, biochemical, physiological and molecular aspects of cadmium toxicity in plants, emphasizing role of trees in phytoremediation studies, especially recent studies on Khaya ivorensis or african mahogany and its cadmium phytoremediation potential.

Keywords: Heavy metal; phytoremediation; chelation; metal compartmentalization; oxidative stress.

Introduction

Heavy metals (HM) are important pollutants for environmental, ecological, nutritional and evolutionary reasons. It has origin of anthropogenic and/or lithogenic processes in the soils (Nagajyoti et al., 2010). These contaminants are introduced into soil by natural process. It includes minerals weathering, volcanic eruptions and erosion when not accelerated or induced by humans (Frohne et al., 2015; Antoniadis et al., 2017).

Rock formations are vast site for heavy metals, mainly in their dispersed form. However, industrialization and urbanization contribute on larger scale to increase concentration of chemicals in biosphere (Rehman et al., 2015).

HMs are widely available in soils and aquatic ecosystems. Also, small amount of HMs are available in atmosphere as particles or vapors, such as lead $(\mathrm{Pb})$, cadmium $(\mathrm{Cd})$, nickel $(\mathrm{Ni})$, arsenic $(\mathrm{As})$, silver $(\mathrm{Ag})$, chrome $(\mathrm{Cr})$, cobalt $(\mathrm{Co})$ and iron (Fe) (Nagajyoti et al., 2010, Gautam et al., 2016; Luo et al., 2016).
These chemical elements constitute a group of metals or metalloids with an atomic density greater than $4 \mathrm{~g} \mathrm{~cm}^{-3}$ or five times or more density of water. However, it should be noted that chemical properties of PM such as bioaccumulation and highly reaction are factors that best determine their classification rather than their density as main characteristics (Hawkes, 1997; Nagajyoti et al., 2010; Kabata-Pendias and Szteke, 2015; Rizwan et al., 2016)

HM toxicity varies depends on plant species, HM type and concentration, chemical form, $\mathrm{pH}$ and soil composition (Sharma and Agrawal, 2005; He et al., 2015). Some of HMs act as cofactor and enzymatic activator such as $\mathrm{Zn}$ and Fe. Others assume functions related to catalytic properties in prosthetic groups in metalloproteins (Ivanov et al., 2016; Mathur et al., 2016).

HMs including $\mathrm{Cd}, \mathrm{Pb}$, and have no known biological functions are are toxic to most living organisms and even low concentrations are highly harmful to MP-sensitive enzymes resulting in reduced growth and death of organism (He et al., 2013; Luo et al., 2016). 
Among HM cadmium (Cd) appears as seventh most toxic, according to United States Agency for Toxic Substances and Disease Registry (ATSDR, 1999) ranking and is among the most widely distributed environmental pollutants from natural or industrial sources (Sabeen et al., 2013; Mead, 2010).

Cd was discovered in 1817 , zinc oxide samples obtained by roasting zinc carbonate in Salzgitter, Germany, by researchers Friedrich Stromeyer and Karl Hermann (Borsari, 2011). Cd is an element of group $2 B$ of periodic table, with an atomic number of 48 and a density of $8.6 \mathrm{~g} \mathrm{~cm}^{-3}$ (Hasan et al., 2009). It is a relatively rare element and is not found in its pure state in nature.

In air, $\mathrm{Cd}$ is rapidly oxidized to cadmium oxide. This nonessential microelement easily reacts with carbon dioxide, water vapor, sulfur trioxide or hydrochloric acid producing carbonate, hydroxide, sulfide or cadmium chloride. Furthermore, it may poorly bond with carbon and other more electronegative atoms (Tran and Popova, 2013). Toxicity to plants has been recorded through reduced growth of shoot and root (Bonet et al., 2016; Akhtar et al., 2017; Anjum et al., 2017).

Decreased photosynthetic activity (Chaffei et al., 2004; Cao et al., 2015; Kaur and Jhanji, 2016) anatomical changes (Castro et al., 2015; Ibrahim et al., 2015; Pereira et al., 2016) and nutritional (Castro et al., 2015; Ibrahim et al., 2015) have been observed in plants.

Leaf concentration above $100 \mu \mathrm{g} \mathrm{Cd} \mathrm{g}{ }^{-1}$ of dry mass is considered exceptional, the values above which in plant is considered hyper-accumulating. The HM hyperaccumulation feature in plants is uncommon and less than $0.2 \%$ of all angiosperms have been classified as hyperaccumulative (Baker et al., 2000).

All plants extract metals from soil, but some plant groups have different ability to extract, accumulate and tolerate high levels of HM that are toxic to organisms (Cunningham and Ow, 1996).

These plants are known as hyperaccumulators and are used as phytoextractors in HM contaminated environments. Success in HM phytoextraction presupposes use of plants with high $\mathrm{HM}$ absorption capacity and high biomass production (Lasat, 2002).

In this review we will address main aspects related to cadmium phytoremediation performed by trees, emphasizing physiological, biochemical and nutritional mechanisms involved, as well as addressing the most recent findings regarding use tree of Meliaceae family, potentially cadmium phytoremediation.

\section{Growth}

The efficient decontamination of areas affected by HM by phytoremediation requires fast growing species, high dry mass production, high tolerance and ability to accumulate Cd in shoots.

Trees are among the best species due to their large size and ability of root system to grow into a greater depths. Considering that a considerable part of phytoremediation studies are based on herbaceous plants, some studies conducted with trees have shown promising results, indicating phytoremediation potential of $\mathrm{Cd}$.

In a study, two trees of Lythraceae family, species Lagerstroemia indica (L. indica) showed high growth compared to Lagerstroemia fauriei (L. fauiei), when grown in a pot condition containing 20, 40 and $80 \mathrm{mg} \mathrm{kg}^{-1} \mathrm{Cd}$. The phytoremediation character of species $L$. indica was evidenced by high translocation factor, which was always high at all concentrations of Cd compared to species $L$. fauriei (Wang et al., 2016). The high growth and translocation factor of $\mathrm{Cd}$ presented by species $\mathrm{L}$. indica, suggests this species as potentially phytoremediation plant, as it presented considerable levels of $\mathrm{Cd}$ in shoots in parallel with low growth reduction and increase of $\mathrm{Cd}$ concentrations in shoots.

In another study involving four species subjected to five concentrations of $\mathrm{Cd}$ under greenhouse conditions, leucena legume (Leucaena leucocephala) showed great phytoremediation potential due to growth gains and large accumulation of $\mathrm{Cd}$ in shoot as a function of $\mathrm{Cd}$ concentrations applied to vessel. In addition, chemical analysis of soil where leucena plants were cultivated after harvesting showed a reduction in $\mathrm{Cd}$ levels, compared to analysis of soil prior to planting. This has evidenced phytoremediation potential of leucena in extracting $\mathrm{Cd}$ and maintaining satisfactory growth (Kaur et al., 2018).

The evaluation of two clones belonging to Salicaceae family showed that species Populos deltoides (clone B-81) has phytoremediation potential with differential tolerance to concentration of $8.14 \mathrm{mg} \mathrm{kg}^{-1} \mathrm{Cd}$ applied to soil under greenhouse conditions. This clone presented high total biomass, root mass, leaf mass and leaf area. In addition, clone presented high $\mathrm{Cd}$ concentration in stem, as well as high biological concentration and translocation factor of stem when cultivated in presence of Cd (Nikolić et al., 2017). The accumulation of $\mathrm{Cd}$ in stem is positive factor because it avoids secondary soil contamination if accumulation of $\mathrm{Cd}$ was in leaves.

Salix dasyclados showed a potential phytoremediation when grown in a pot containing soil moderately contaminated with $\mathrm{Cd}\left(5.46 \mathrm{mg} \mathrm{kg}^{-1}\right)$. This species showed pronounced growth, besides accumulating high levels of $\mathrm{Cd}$ in leaves and branches (57.5 and $28.7 \mathrm{mg} \mathrm{kg}^{-1}$, respectively) without showing symptoms of Cd toxicity (Fuksová et al., 2009).

Another species with phytoremediation potential is Populus trichocarpa. This species showed high tolerance to $\mathrm{Cd}$ toxicity as it did not show significant differences in total biomass production between $\mathrm{Cd}$ treatments, except for the highest $\mathrm{Cd}$ dose of $243 \mathrm{mg} \mathrm{kg}$. However, up to limit concentration of $27 \mathrm{mg} \mathrm{kg}^{-1}$, Populus trichocarpa was highly tolerant to Cd toxicity (de Oliveira and Tibbett, 2018).

Dendropanax cuneatum ( $D$. cuneatum) showed considerable total accumulation of $697 \mu \mathrm{g} \mathrm{kg}{ }^{-1} \mathrm{Cd}$ with $63 \%$ of total accumulated in stem of plants in $\mathrm{Cd}\left(135 \mathrm{mg} \mathrm{kg}^{-1}\right)$ contaminated dark red (LE) Oxisol mixed with LE but uncontaminated, in proportion of 40 and $60 \%$ (contaminated/uncontaminated soil, respectively). The high accumulation of $\mathrm{Cd}$ in stem of Dendropanax cuneatum showed potential of this specie in phytoremediation of $\mathrm{Cd}$ contaminated soil and reduction of $\mathrm{Cd}$ secondary soil contamination from leaf accumulation (Soares et al., 2001).

\section{Antioxidant mechanisms}

Reactive oxygen species (ROS) or reactive oxygen intermediates (ROI) are partially reduced forms of atmospheric oxygen $\left(\mathrm{O}_{2}\right)$. They typically result from electronic excitation of $\mathrm{O}_{2}$ to form singlet oxygen $\left(\mathrm{O}_{2}{ }^{1}\right)$ or transfer one, two or three electrons to $\mathrm{O}_{2}$ to form respectively superoxide radical $\left(\mathrm{O}_{2}-\right)$, hydrogen peroxide $\left(\mathrm{H}_{2} \mathrm{O}_{2}\right)$ or hydroxyl radical $\left(\mathrm{OH}^{-}\right)$(Mittler, 2002).

ROS promote oxidation of various cellular components and leads to oxidative destruction of cells in phenomenon called 
oxidative stress. They are capable to induce cellular damage through protein degradation, enzyme inactivation, alterations in genes what interferes in metabolic pathways (Dat et al., 2000; Choudhury et al., 2013).

Oxidative stress comes from an imbalance between synthesis of oxidant and antioxidant compounds, in which former is considerably increased (Vaidyanathan et al., 2003; Gill and Tuteja, 2010). Despite harmful effect on cells, ROS are usually produced due to photosynthetic and respiratory cell metabolism (Mittler, 2002).

In addition, plants use ROS as molecules to regulate development and various physiological responses such as growth, cell cycle and programmed cell death (Kovtun et al., 2000; Pitzschke et al., 2006; Veal et al., 2007). However, under stressful conditions (i.e., salt stress, water deficiency or excess, heavy metal toxicity or elevated temperatures) plants increase their yield.

$\mathrm{Cd}$ is not directly involved in redox reactions and; therefore, cannot change its oxidation state in plant cells as it does not participate in Fenton and Haber-Weiss reactions (Cuypers et al., 2011; Liu et al., 2015; Khan et al., 2013).

It appears that $\mathrm{Cd}$ can indirectly activate membrane NADPH oxidases, inducing higher production of ROS such as $\mathrm{O}_{2}$ and $\mathrm{H}_{2} \mathrm{O}_{2}$, eventually lead to an oxidative explosion (He et al., 2013; Choppala et al., 2014). The mechanism of Cd triggered ROS production involving activation of protein, NADPH oxidase, which is regulated by free $\mathrm{Ca}$ and ethylene.

To increase $\mathrm{Ca}$ levels plants require phospholipase $\mathrm{C}$ activity as well as involvement of 3-phosphate inositol in activation of calcium channels and ADP ribose (adenosine triphosphate ribose). In addition, $\mathrm{Cd}$ and $\mathrm{Ca}$ induced $\mathrm{ROS}$ production is triggered by reaction cascade involving calmodulin, protein kinases, phospholipase $C$ and $D$.

Phospholipase also initiates signalization by increasing levels of phosphatidylinositol triphosphate (IP3) or phosphatidic acid. These molecules act by activating secondary messengers such as lipids and protein kinase, including 3phosphatylinositol kinase, mitosis activates protein kinases and calcium dependent protein kinases.

Activation of $\mathrm{Cd}$ induced mitosis activating protein kinases requiring not only ROS, but also calcium-dependent protein kinases and 3-phosphatylinositol kinase. It also may be triggered by closure of mitochondrial permeability transition pore. ROS induced secondary messengers can modify transcription factors, affecting expression of plant signalization and gene-promoted defense. ROS are associated with signal transduction in conjunction with nitric oxide, leading to necrosis and programmed cell death (Chmielowska-Bak et al., 2014).

Prolonged exposure to $\mathrm{Cd}$ causes high ROS production, causing oxidative damage. $\mathrm{H}_{2} \mathrm{O}_{2}$ is formed in the same cell sites as $\mathrm{O}_{2}$. In high concentration in cell, it inhibits carbon fixation activity such as many Calvin cycle enzymes which are are extremely sensitive to $\mathrm{H}_{2} \mathrm{O}_{2}$. Also, it breaks cell membranes and cause damage to DNA (Scandalios et al., 2000).

Autors $\mathrm{He}$ et al. (2013) showed that exposure to $\mathrm{Cd}$ increased levels of ${ }^{1} \mathrm{O}_{2}$ and $\mathrm{H}_{2} \mathrm{O}_{2}$ in root tissues of two varieties of Populus (Populus cathayana e Populus deltoides), when compared to control.

In pine tree (Pinus sylvestris), Tran and Popova (2013) demonstrated that treatment with $50 \mu \mathrm{M} C d$ increased levels of $\mathrm{O}_{2}{ }^{-}$and $\mathrm{H}_{2} \mathrm{O}_{2}$ in roots in just $6 \mathrm{~h}$ after initiation of treatment with metal.

Cuypers et al. (2011) reported ability of $\mathrm{Cd}$ to induce highest production of ROS as a result of oxidative damage, which causes redox homeostasis impairment and leading to emergence of secondary stress, oxidative stress (Chen et al., 2014; Tauqeer et al., 2016).

\section{Sequestration, compartmentalization and cadmium} partition in trees

In MP exclusive plants, roots impose restriction on absorption of HM by retention, which avoids dispersion of contamination in aerial organs, preventing appearance of toxic effects, especially in photosynthetic apparatus of plants (Li et al., 2015; Liu et al., 2015; Lysenko et al., 2014).

The root cell wall (PC) positively contributes to $\mathrm{Cd}$ retention and constitutes first barrier protecting protoplast from $\mathrm{Cd}$ toxicity (Chen et al., 2014; Mahar et al., 2016). The negative charges resulting from dissociation of carboxylic groups (COO-) from galacturonic and glucuronic acids of root cell wall, mainly rhizoderm and córtex makes sequestration of Cd possible. In addition, barriers imposed by Casparian strips and plasmalema of endoderm cells represent mechanisms that restrict Cd's access to xylem, reducing translocation to plant shoots. Similarly, pectin and cellulose functional groups of root tissue cell wall can complex metalloids (Chen et al., 2014; Pereira et al., 2017; Pietrini et al., 2015).

In studies of woody plants, sequestration of $\mathrm{Cd}$ by constituents of root cell wall were found, which evidences sequestration of $\mathrm{Cd}$ as primary tolerance mechanism of these species to phytotoxic effect of Cd (Chen et al., 2014; He et al., 2013).

In research on Eucalyptus camaldulensis, Souza et al. (2013) showed that under high concentrations of $\mathrm{Cd}$ metal was sequestered by cell walls of root cortex of plants. According to authors, this fact may be related to chelation of $\mathrm{Cd}$ by organic acids present in root exudates, which contributed to low translocation of $\mathrm{Cd}$ to organs of aerial part of plants.

An increase in root PC thickness has also been observed in response to $\mathrm{Cd}$ contamination. In this case, plant maximize filtering capacity by increasing negative charge and protecting inner tissues that comes from damage effects of heavy metals (Souza et al., 2013; Shi et al., 2015).

In fact, radial rise of $\mathrm{Cd}$ in plants is limited by root system and development of endoderm, exodermis and other extracellular barriers that may restrict $\mathrm{Cd}$ translocation to xylem (Lux et al., 2011; Fontanili et al., 2016).

Metal ions are probably adsorbed to cellular matrices or apoplast components that is unavailable to transport. In addition, movement of $\mathrm{Cd}$ through simplasto is reduced by production of non-protein thiol compounds (Cao et al., 2018; Xu et al., 2017).

Some studies have show negative correlation between thiol group content and variation of $\mathrm{Cd}$ concentration inside plants, indicating that thiol metabolism may limit flow of $\mathrm{Cd}$ (Nocito et al., 2011; Mahar et al., 2016; Xu et al., 2017).

In this sense, chelation of $\mathrm{Cd}$ by thiol-peptide compounds in roots regulates systemic ion homeostasis and ensures great retention of $\mathrm{Cd}$ in roots (Xu et al., 2017; Cao et al., 2018). The movement of metal ions is only possible as non-cationic metal chelates because cell walls have comparatively high cation exchange capacity (Thakur et al., 2016; Cao, et al., 2018). Under limiting concentrations of $\mathrm{Cd}$ in plant tissue there is increased synthesis of high (HMW) and low (LMW) molecular weight chelators such as glutathione (GSH) and phytocellatins (PCs), which facilitate transport of $\mathrm{Cd}$ to vacuoles (Fontanili et al., 2016; Mahar et al., 2016; Thakur et al., 2016; Xu et al., 2017). 
Studies by Souza et al. (2013) suggest that synthesis of phytoalequitins is influenced to great or less extent according to affinity for stressor metal. In this sense, Cd appears as MP that determines highest synthesis of peptide, followed in sequence by $\mathrm{Pb}^{2+}, \mathrm{Zn}^{2+}, \mathrm{Sb}^{3+}, \mathrm{Ag}^{+}, \mathrm{Hg}^{2+}$. The phytocellatin of $\mathrm{Cd}$ complex has about 1,000 times lower phytotoxicity than free Cd ions (Stolt et al., 2003; Olguín et al., 2007). Different root mechanisms contribute positively to high $\mathrm{Cd}$ retention, leading to apoplastic barriers, synthesis of chelating molecules such as phytalekithins and vacuolar sequestration. These factors are main processes that mediate Cd retention in roots (Gomes et al., 2011; Sghayar et al., 2015; Cui et al., 2016).

The results of metal chelating complex is actively transported from cytosol by ATP dependent transporters present in vacuole tonoplast. Binding of phytoalequitins to Cd decreases cytosol activity and toxicity (Cobbett, 2000; Stolt et al., 2003). For example, Vögeli-Lange and Wagner (1990) studied protoplasts isolated from mesophyll of tobacco plants (Nicotiana rustica var. pavonii) exposed to $\mathrm{Cd}$ and reported that metal was chelated by phytoalequitins (PCs) and Cd PC complex was actively transported to vacuole through tonoplast.

Cell wall and vacuoles are primary subcellular fractions for Cd storage (Li et al., 2017; Cao et al., 2018). Vacuolar seizure is one of main events that clarify differences in variation of $\mathrm{Cd}$ retention in plant roots. Vacuum sequestration mainly depends on activity of transporters located in tonoplasts (Mendoza-Cózatl et al., 2010; Sharma et al., 2016) and number of $\mathrm{Cd}$ ions (free and retained $\mathrm{Cd}^{2+}$ in thiol-peptide complexes) in cytosol.

Previous studies have shown an increase in root meristematic cell vacuolation in Cd treated plants, which has been attributed to chelation of metal to low molecular weight compound and transport and sequestration in vacuoles (Verbruggen et al., 2009; Fan et al., 2011; Batista et al., 2014). In vacuole, $\mathrm{Cd}$ dissociation with $\mathrm{HMW}$ compounds occurs due to vacuolar $\mathrm{pH}$. In free form, ions bind, even with cell compartment or organic acids and amino acids (Zoghlami et al., 2011; Li et a., 2017).

After crossing walls of root cells, $\mathrm{Cd}$ reaches plasma membrane (MP). $\mathrm{H}^{+}$ATPases control MP polarization through formation of an electrochemical gradient as driving force, which is fundamental for transport of ions such as $\mathrm{Mg}^{2+}, \mathrm{Ca}^{2+}, \mathrm{Fe}^{2+}, \mathrm{Cu}^{2+}, \mathrm{Mn}^{2+}$ and $\mathrm{Zn}^{2+}$ across membrane and otherwise suppress input of toxic ions in cell compartments (Gallego et al., 2012; Clemens et al., 2013; Song et al., 2014; Shi et al., 2015; Stoláriková-Vaculíková et al., 2015; Pereira et al., 2017).

Some species show ability to tolerate and accumulate heavy metals (Liu et al., 2013). Depending on MP, plants can accumulate them in different organs. Accumulation of $\mathrm{Cd}$ varies in plant structures (i.e., root, stem, branches and leaves) in different trees and may be high in root compared to leaves. Table 1 shows different species that can accumulate $\mathrm{Cd}$ in shoot (stem, branches or leaves) or root.

\section{Mechanisms cadmium absorption}

$\mathrm{Cd}$ is a nonessential and toxic element to plants. Even under low concentration, plants manifest symptoms of toxicity evidenced by reduced photosynthetic rate, nutritional imbalance and decreased growth.

Although Cd may be in atmosphere in form of particles and vapor, absorption by plants occurs mainly from root with translocation to aerial part. This absorption mechanism is more important in agricultural environments because rate of deposition of $\mathrm{Cd}$ in air is typically less than $2 \mathrm{~g} \mathrm{ha}^{-1}$ year $^{-1}$ (Smolders, 2001).

$\mathrm{Cd}$ uptake by plants is modulated by set of factors such as $\mathrm{pH}$, temperature, aeration, total soil $\mathrm{Cd}$ concentration and presence of macro and micronutrientes (McLaughlin et al., 1999).

In plants, primary xylem transport, phloem retranslocation and xylem transfer to phloem are important processes of translocation of an element within plant (Marschner, 2012). The transport in xylem is directed to aerial part through transpiratory current, while in phloem transport occurs from source to drain, being more selective (Marschner, 2012).

Root cell absorption of $\mathrm{Cd}$ from rhizosphere is mediated by OsIRT1 and OsNRAMP5 membrane transporters, according to proposed model for Oriza sativa (Gao et al., 2016).

These transporters are located in plasma membrane of root cells which allows passage of $\mathrm{Cd}$ located in rhizosphere into cells. After entering root cell, part of $\mathrm{Cd}$ is chelated, forming $\mathrm{Cd}$ - phytocellatin complex, which is sequestered in vacuoles. After entering root cell, part of $\mathrm{Cd}$ is chelated, forming $\mathrm{Cd}$ phytocellatin complex, which is sequestered in vacuoles. In root, the other part is translocated to aerial part via xylem and passes to phloem through OsHMA2 transporter (Li et al., 2017).

The OSLCT1 and OsHMA2 transporters are located in node region and base of shoot. The OSIRT1 transporter is located in root epidermis and exodermis cells and in stele (vascular cylinder) cells. In turn, OsNRAMP5 transporter is located in root epidermis, exodermis and endoderm cells.

In phloem, $\mathrm{Cd}$ binds to specific proteins and weakly to thiol groups called glutathione - GSH (Figure 1) (Yoneyama et al., 2015).

In tonoplast, there is OsHMA3 transporter, which allows passage of $\mathrm{Cd}$ - phytocellatin and sequestration in vacuoles (White and Broadley, 2011). This mechanism of Cd sequestration in root cell vacuoles is strategy of stress tolerance for $\mathrm{Cd}$, as it prevents translocation to shoot and appearance of $\mathrm{Cd}$ toxicity symptoms.

On the other hand, there is another mechanism called avoidance, in which plant presents physical mechanism such as Casparian strips (Figure 2) or exudes a set of compounds (sugars, proteins and organic acids) that prevent entry of $\mathrm{Cd}$ inside xylem cell, a strategy adopted by plant to avoid $\mathrm{Cd}$ toxicity.

Plants have ability to absorb and translocate Cd differently. Plants considered as accumulators have a considerably high Cd content in aerial part (leaves, branches or stem) compared to non-accumulators.

The value of threshold concentration separating accumulative and nonaccumulative plants is $100 \mathrm{mg} \mathrm{kg}^{-1} \mathrm{dry}$ mass of shoot (Baker and Brooks, 1989). Cd levels in shoot above this value indicate that species is phytoremediator (Barker et al., 2000).

However, few species have capacity to accumulate $\mathrm{Cd}$ contents above $100 \mathrm{mg} \mathrm{kg}^{-1}$. Only species Populus tricocarpa $\times$ P. deltoides (Robinson et al., 2000), Salix caprea (Lepp and Madejón, 2007; Unterbrunner et al., 2007) and Salix $x$ smithiana (Wieshammer et al., 2007) accumulated more $\mathrm{Cd}$, above $100 \mathrm{mg} \mathrm{kg}^{-1}$. Due to large biomass production of leaves, branches and trunks, trees have potential for MP phytoextraction.

As one of main products of silvicultural exploitation is wood from trunk, phytoextraction and immobilization of MP in these structures allows almost total removal of MP from contaminated area. 
Table 1. Preferred accumulation of $\mathrm{Cd}$ in different organs of tree species.

\begin{tabular}{|c|c|c|}
\hline Species & Organs & Authors \\
\hline Melia azirach & Root $>$ Stem $>$ Leaf & Khamis et al. (2014) \\
\hline Populus alba & Root $>$ Leaf $>$ Stem & Khamis et al. (2014) \\
\hline Populus alba & Root $>$ Green leaf $>$ Stem=Fallen leaf & Rafati et al. (2011) \\
\hline Ulmus laevis & Root $>$ Leaf $>$ Stem & Mleczec et al. (2017) \\
\hline Quercus rabur & Root $>$ Stem $>$ Leaf & Mleczec et al. (2017) \\
\hline Acer platanoides & Root $>$ Stem $>$ Leaf & Mleczec et al. (2017) \\
\hline Acer pseudoplatanus & Root $>$ Stem $>$ Leaf & Mleczec et al. (2017) \\
\hline Betula pendula & Root $>$ Stem $>$ Leaf & Mleczec et al. (2017) \\
\hline Quercus robur & Root $>$ Stem $>$ Leaf & Mleczec et al. (2017) \\
\hline Tilia cordata & Root $>$ Stem $>$ Leaf & Mleczec et al. (2017) \\
\hline Acacia mangium & Stem $>$ Leaf $=$ Root & Majid et al. (2012) \\
\hline Prosopis juliflora & Leaf $>$ Root & Varun et al. (2011) \\
\hline Populusxeuramericana cv. 'Neva' & Root $>\mathrm{B}>\mathrm{YL}>\mathrm{S}>\mathrm{ML}>\mathrm{W}^{*}$ & Ge et al. (2012) \\
\hline Populus nigraxPopulus ussuriensis & Root $>\mathrm{YL}>\mathrm{B}>\mathrm{S}>\mathrm{ML}>\mathrm{W}^{*}$ & Ge et al. (2012) \\
\hline Gamblea innovans & Root $>$ Stem $>$ Leaf & Hayakawa et al. (2011) \\
\hline Salix discolor & Root $>$ Wood $>$ Stem & Kuzovkina et. (2004) \\
\hline Salix eriocephala & Root $>$ Stem $>$ Wood & Kuzovkina et. (2004) \\
\hline Salix exigua & Root $>$ Wood $>$ Stem & Kuzovkina et. (2004) \\
\hline Salix lucida & Root $>$ Wood $>$ Stem & Kuzovkina et. (2004) \\
\hline Salix nigra & Root $>$ Wood $>$ Stem & Kuzovkina et. (2004) \\
\hline
\end{tabular}

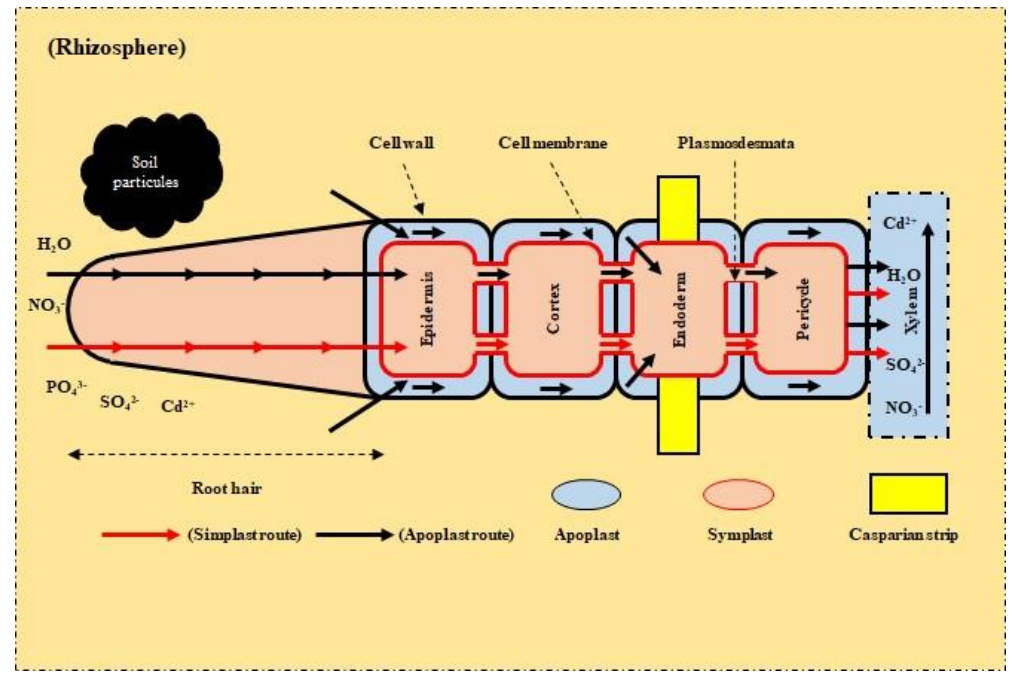

Fig 1. Cadmium absorption and sequestration mechanism in plants. Proposed model for rice. Adapted from Gao et al. (2016).

Table 2. Phytoextractor potential of tree species in soils with different cadmium contents.

\begin{tabular}{lll}
\hline Species & Cd content in growth substrate & Author \\
\hline Dendropanax cuneatum & $74 \mathrm{mg} \mathrm{dm}^{-3}$ & Soares et al. (2001) \\
Salix dasyclados & $5.46-60 \mathrm{mg} \mathrm{kg}^{-1}$ & Fuksová et al. (2009) \\
Salix spp & $0.42-30,5 \mathrm{mg} \mathrm{kg}^{-1}$ & Vysloužilová et al. (2003) \\
Lagerstroemia indica & $0 \mathrm{a} 80 \mathrm{mg} \mathrm{kg}^{-1}$ & Wang et al. (2016) \\
Averrhoa carambola & $0.51 \mathrm{mg} \mathrm{kg}^{-1}$ (Extractable) & Dai et al. (2011) \\
Averrhoa carambola & $12 \mathrm{mg} \mathrm{kg}^{-1}$ & Li et al. (2010) \\
Populus trichocarpa & $27 \mathrm{mg} \mathrm{kg}^{-1}$ & Oliveira e Tibbett (2018) \\
Swietenia macrophylla & $15 \mathrm{mg} \mathrm{L}^{-1}$ & Fan et al. (2011) \\
Populus deltoids $\times$ Populus nigra & $4.28 \mathrm{mg} \mathrm{kg}^{-1}$ & Wu et al. (2010) \\
Leucaena leucocephala & $40 \mathrm{mg} \mathrm{kg}^{-1}$ & Kaur et al. (2018) \\
\hline
\end{tabular}




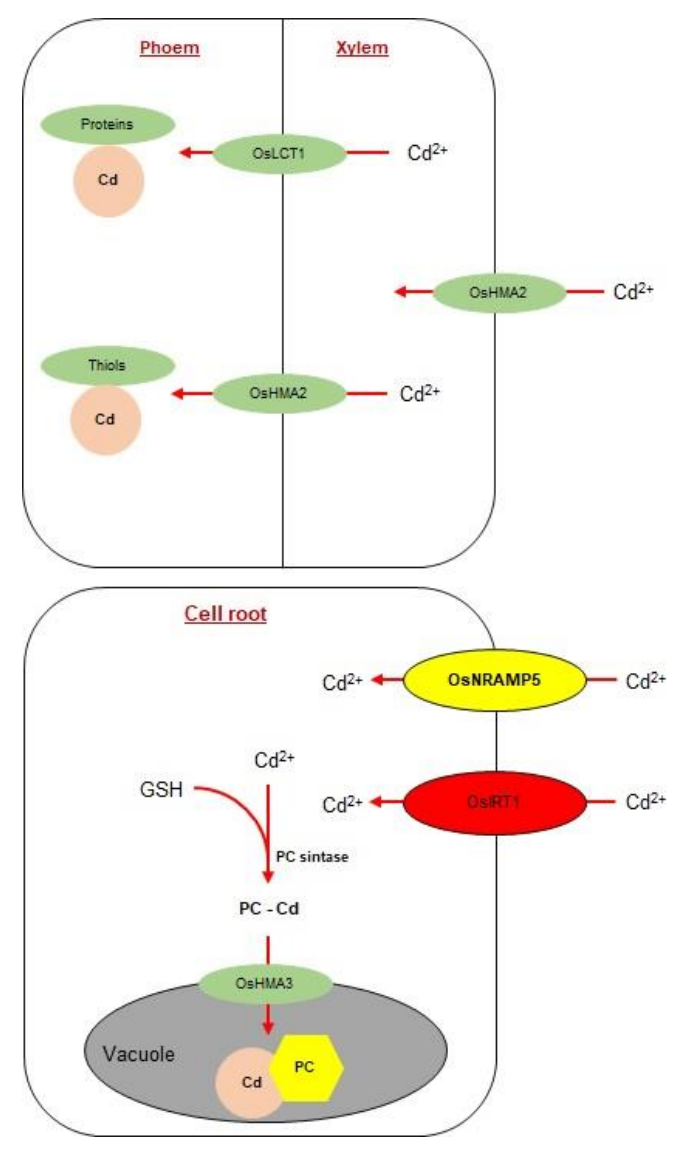

Fig 2. Symplastic and apoplastic flow of water and mineral nutrients. The presence of Casparian strips limits the passage of heavy metals into the xylem. Casparian strips are important physical barriers to xylem absorption and translocation of $\mathrm{Cd}$ to the shoot in a mechanism called avoidance. The exoderm-coupled endoderm also acts as a barrier to the passage of $\mathrm{Cd}$. Simplast and apoplast are involved in Cd absorption. Cd absorption is modulated by OsIRT1 and OsNRAMP5 transporters located on the plasma membrane.
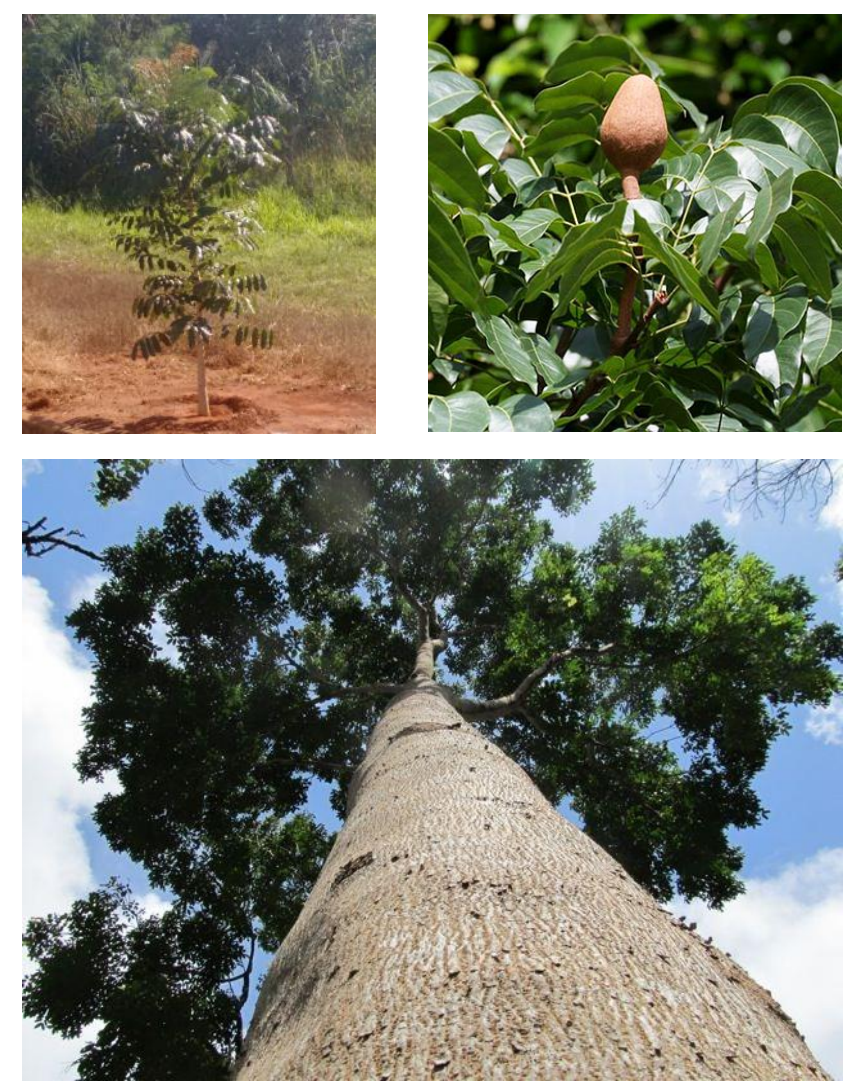

Fig 3. Young plant, adult plant and reproductive structure of mahogany (Khaya ivorenses) a potential tree phytoremediator. 

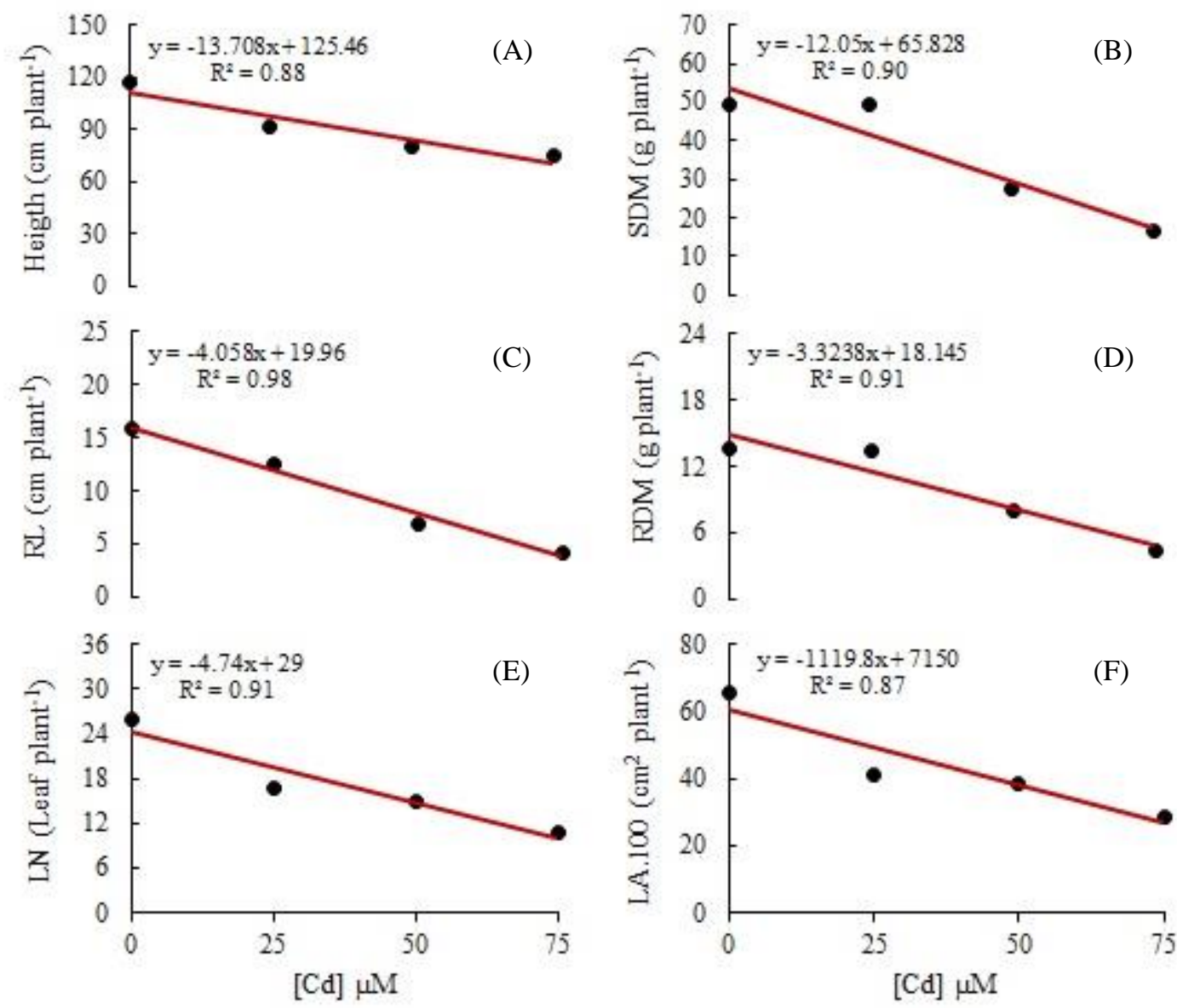

Fig 4. Height (A), shoot dry matter (B), root length (C), root dry matter (D), leaf number (E) and leaf area (F) of young plants of Khaya ivorenses (three hundred day old plants) submitted to $\mathrm{Cd}$ concentration.

However, leaves and branches must be properly disposed so that secondary PM contamination does not occur. Therefore, phytoextracting capacity of a species is determined by two factors: metal concentration in aerial part and biomass production in aerial part. Plants suitable for phytoextraction should have good shoot biomass production and ability to accumulate and transport $\mathrm{Cd}$ to shoot.

\section{Plant nutritional disorder and Cd toxicity}

HMs conflict with essential nutrients, a relationship that can be antagonistic or synergistic with accumulation of species organ dependent HM. The relationship between $\mathrm{Cd}$ and essential nutrients may imply emergence of nutritional disorders that accompany reduction of plant growth.

For example, $\mathrm{Cd}$ competes with $\mathrm{Ca}^{+2}$ for same membrane transporter during root absorption process and may decrease $\mathrm{Ca}^{+}{ }^{2}$. Influx may be replaced with membrane phospholipid bonds.

In poplar clone I-214, application of $150 \mu \mathrm{M}$ Cd reduced leaf Ca content by $23 \%$ and plant dry mass (Di Baccio et al., 2014). False - open presence of $0.5 \mu \mathrm{M}$ reduces root $\mathrm{Ca}$ content by $17.5 \%$ (Österås and Greger, 2006).

On the other hand in Cedar, application of $0,22,44,88$ and $132 \mu \mathrm{M}$ of $\mathrm{Cd}$ did not alter root $\mathrm{Ca}$ levels, but promoted a significant linear and quadratic increase in $\mathrm{Ca}$ and stem contentes, respectively (Paiva et al., 2001).
Despite conflicts in some results, Ca reduces $\mathrm{Cd}$ toxicity by decreasing absorption and competing $\mathrm{Cd}$ transport site. In addition, liming or alkaline media reduces $\mathrm{Cd}$ absorption, which is facilitated by low $\mathrm{pH}$ (Naeem et al., 2019).

In Pinus pinea, concentration of $5 \mu \mathrm{M} \mathrm{Cd}$ considerably reduced leaf and root $\mathrm{Ca}$ contents, while $\mathrm{Mg}$ levels were reduced only in leaves. On the other hand, in Pinus pinaster $\mathrm{Ca}$ and $\mathrm{Mg}$ contents increased in leaves and roots, showing differential genotypic response to $\mathrm{Cd}$ toxicity (Arduini et al., 1998). This same differential genotypic pattern of $\mathrm{Cd}$ response was observed in Populus tremula $\times$ Populus alba. The cultivation in presence of $360 \mathrm{mg} \mathrm{kg}^{-1}$ of $\mathrm{Cd}$ increased contents of $\mathrm{Mg}, \mathrm{K}$ in leaf and $\mathrm{Zn}$, and $\mathrm{Fe}$ in roots. $\mathrm{K}$ contents were reduced in roots (Durand et al., 2010). Macro and micronutrient deficiency in plants may be due to indirect effect of $\mathrm{Cd}$ on mineral nutrients through role in inhibiting $\mathrm{H}^{+}$ ATPases. It is assumed that $\mathrm{Cd}$ can bind to electron bombs by changing conformation and causing inactivation. $\mathrm{H}^{+}$ ATPases use an electrochemical gradient as driving force, thereby controlling transport of ions across membrane, which is supposed to depend on lipid composition of organelle (Tran and Popova, 2013; Rivelli et al., 2014; Matraszek et al., 2016).

Thus, decrease in $\mathrm{H}^{+}$ATPase activity due to toxic effect of $\mathrm{Cd}$ may inhibit absorption of some essential mineral nutrients, which causes imbalances in cellular homeostasis, loss of MP permeability and lipid peroxidation (Astolfi et al., 2005). 
Hernandez and Cooke (1977) reported modifications in plasma membrane lipid composition in Pisum sativum roots treated with $\mathrm{Cd}$. This effect may have caused variation in membrane selectivity. Biochemical events results of decreased membrane fluidity include: interference with protein functions, reduced energy supply, loss of compartmentalization, and electrolyte leakage.

Therefore, it is plausible that changes in MP (loss of selective permeability) due to toxicity by $\mathrm{Cd}$ cause a decrease in absorption or translocation of potassium ions (K) from roots to aerial parts. The role of these nutrient in stomatal regulation determines gas exchange processes in plants with negative implications for plant growth and development (Nocito et al., 2011; Saifullah et al., 2014; Pereira et al., 2017).

In addition, Cd competes with iron (Fe) for same absorption site or membrane carriers, which implies reduction of absorption of micronutrient by plant and emergence of Fe deficiency as reported for a large number of plants (Konlechner et al., 2013; Solti et al., 2011; Kabata-Pendias, 2011; Chmielowska-Bak et al., 2014; Gong et al., 2015; Rahman et al., 2017).

The visible symptoms of Fe deficiency due to $\mathrm{Cd}$ poisoning can appear as brown spots on leaves and roots, atrophy of latter organ and chlorosis (John et al., 2008; Kabata-Pendias, 2011). Pereira et al. (2017) observed decreases in $\mathrm{Fe}^{+2}$ concentration in leaves of Calophyllum brasiliense Cambess, which reflected in decrease of photosynthetic activity due to reductions in chlorophyll contents.

It seems that $\mathrm{Cd}$ induces similar symptoms to Fe deficiency. It also has its own mechanism of cell toxicity, which has specific targets such as aminos acid residues in multiprotein complexes. In addition, Fe deficiency increases susceptibility of multiprotein complexes to toxic effect of $\mathrm{Cd}$ (Qureshi et al., 2010; Basa et al., 2014).

This suggests that $\mathrm{Cd}$ not only causes micronutrient deficiency, but also triggers stress and induces cell damage.

The primary consequence of toxic effect of $\mathrm{Cd}$ is on absorption and assimilation processes of essential minerals. For example, changes in water relations, plant anatomy and morphology decreases growth and development may occur. Also, photosynthetic metabolism of plant species, conformational and functional alteration of enzymes, proteins, especially cytosolic can happen (Verbruggen et al., 2009; Choppala et al., 2014; Liu et al., 2015).

In plants with lack of $\mathrm{Cd}$ tolerance mechanism, this ion is easily translocated by xylem current to intracellular spaces reaching chloroplasts, which affect their structure and function. Chloroplasts are one of the major sites of action of abiotic stresses including toxicity by $\mathrm{Cd}$ and other metals and semimetals (Anjum et al., 2016).

The main targets of metal in this cell compartment are two enzymes involved in $\mathrm{CO}_{2}$ fixation process, essential for photosynthesis, ribulose $-1,5-\quad$ bisphosphate carboxylase/Oxygenase (RuBisCo), which affects photosystem I and II activity.

Cd reduces RuBisCo activity and cause damage in its structure by replacing $\mathrm{Mg}^{2+}$ ion present in catalytic center, which appears like an important cofactor for carboxylation reaction. Cd can also displace RuBPCase activity to oxygenation reactions, which induces photorespiration (Tran and Popova, 2013; Wang et al., 2014). Processes such as gas exchange, water balance and stomatal conductance are reduced (Choppala et al., 2014; Wang et al., 2014; Luo et al.,
2016; Rizwan et al., 2016; Rahman et al., 2017) due to Cd toxicity.

$\mathrm{Cd}$ has a great effect on $\mathrm{Chl}$ a/Chl b II protein complex and light energy uptake, in part by inducing a reduction in chloroplast density or by displacing $\mathrm{Mg}^{+2}$ ion from chlorophyll tetrapyrrolic, leading to functionality with considerable reduction in content of chlorophyll pigments act in cellular protection against cytotoxic compounds to plant metabolism (Krupa, 1988; Tran and Popova, 2013).

In this process, $\mathrm{Cd}$ can replace $\mathrm{Ca}^{2+}$ ions in $\mathrm{Ca} / \mathrm{Mn}$ clusters constitute reaction sites of water oxidation complex (OEC), causing no function and blocking electron transport. The toxicity of Cd to PSII reactions results from structural changes promoted by metal in electron transport proteins, plastoquinones $(\mathrm{Qb})$, inducing low photosynthetic regulation (Sigfridsson et al., 2004; Tran and Popova, 2013).

Therefore, $\mathrm{Cd}$ inhibits photosynthesis by reducing photosystem II activity, which eventually suppresses quantum production and electron transport. It leads to an increase in concentration of cytotoxic compounds to plant species such as ROS that cause oxidative stress (Tran and Popova, 2013; Choppala et al., 2014; Pereira et al., 2017).

\section{Use of phytoextraction in trees}

Vegetables are able to adapt various growth environments and few places are devoid of their presence. Some species have ability to interact with other organisms such as arbuscular mycorrhizal fungi and nitrogen that fixes bacteria, which facilitate adaptation of plants to saline, acid, poor or rich in fertility. In this situation, plants that have good biomass production and ability to extract MP from soil and translocate them to aerial part are considered as MP phytoextractors. Phytoextraction consists of using plants to decontaminate polluted soils by heavy metals and organic products.

This technology reduces MP contents to levels safe and not harmful to human health, preventing spread of contamination through food chain and improving chemical, physical and microbiological attributes of soil. The feasibility of this technology is low cost of implementation, despite time required to have positive effects.

After absorption by root system and translocation of MP to aerial part of plants, harvested biomass can have several destinations such as biogas production or incineration. Incinerated plant biomass can be used for recovery of MP, fixing MP on bricks or disposed on deserted land (Ashraf et al., 2013). In trees, seasonality, age and phenology are factors that affect accumulation of MP.

The accumulation of MP ( $\mathrm{Cd}, \mathrm{Co}, \mathrm{Cu}, \mathrm{Cr}, \mathrm{Ni}, \mathrm{Pb}$ and $\mathrm{Zn}$ ) in trees of Salix viminalisi has been studied throughout plant age. Thus, two and three years old plants were more efficient in promoting phytoextraction, besides tolerating stress by MP and presenting ability to adapt in comparison to first year of evaluation.

In the first year of evaluation, plants presented high MP accumulation in relation to third one, supposed to dilution effect due to expressive plant growth (Dinelli and Lombini, 1996; Mleczek et al., 2009; Pulford and Watson, 2003).

In another study effect of plant seasonality and age on MP accumulation in Salix fragiles plants cultivated in contaminated sediment areas was evaluated. There were less extraction capacity of four and six years old species compared to one and two years old plants. 
These results were related to effect and dilution, availability of $\mathrm{Cd}$ in root zone and root activity (Mertens et al., 2006). Seasonal variations in $\mathrm{Cd}$ content of leaves of Evodiopanax innovans are reported with leaf age, budding in April until leaf fall in November (Takenaka et al., 2009).

Phytoextraction as mechanism of decontamination of soil polluted by MP has advantage of low or zero energy use, except for solar energy being used by plants for photosynthesis. Plants can be easily monitored against microorganisms because some species can grow in soils with levels of toxic elements, in which microorganisms would not grow.

Plants promote improvements in physical, chemical and microbiological quality as they increase porosity, fertility and water infiltration as well as provide and recycle nutrients. On the other hand, phytoextraction does not fully reduce concentration of soil pollutants. Phytoextractors must have good biomass production and ability to extract pollutants from soil. A disadvantage of phytoremediation is positive results take longer if compared to other MP remediation technologies.

In general, trees with phytoextraction potential for $\mathrm{Cd}$ have phytoextraction capacity in substrates with variable levels of $\mathrm{Cd}$, but depends on soil type, $\mathrm{pH}$, organic matter content and trees (table 2).

\section{Potential phytoextractor of mahogany}

Mahogany (Swietenia macrophylla King) is considered one of main neotropical species (Figure 3 ) due to great commercial value of its wood. It belongs to family of Meliaceas, having a trunk with $3.7 \mathrm{~m}$ in diameter and height of $20-27 \mathrm{~m}$ in height before forming branches, with capsule like fruits and samaranoid seeds (Lima Júnior and Galvão, 2005).

However, as a result of decades of illegal logging, this species has been in serious danger of extinction as its natural renewal does not occur in same speed as commercial demand (Souza et al., 2008; Souza et al., 2010; Free et al., 2014; Negreros-Castillo et al., 2018).

This species, besides being great timber seems to tolerate toxicity of $\mathrm{Cd}$ (Fan et al., 2011) and survive contamination by crude oil petroleum (Pérez-Hernández et al., 2013). Despite experimental evidence on phytoremediation potential of mahogany, studies on tolerance of this species to $\mathrm{Cd}$ toxicity still incipient.

Preliminary data shows that mahogany has little tolerance to increasing concentrations of $\mathrm{Cd}$ in nutrient solution with negative impact of $\mathrm{Cd}$ on growth of young mahogany plants. In general, concentrations above $25 \mu \mathrm{M}$ cadmium chloride reduce growth (Figure 4). However, under concentrations $\leq$ $25 \mu \mathrm{M} \mathrm{Cd}$, plants did not show significant decreases in growth variables.

This suggests that this specie has efficient mechanisms of accumulation and compartmentalization of $\mathrm{Cd}$ in tissues, which may guarantee tolerance and survival in environments contaminated with $\mathrm{Cd}$. These results, although preliminary, match findings of Fan et al. (2011) suppositing of phytoextraction capacity of Swietenia macrophylla.

\section{Final considerations}

In several countries, anthropogenic activity has significantly contributed to soil pollution and heavy metal water resources, particularly, through activity of mineral exploration and improper disposal of products that include heavy metals such as batteries and cell phones.

This fact has raised great concern from environmental agencies that signal increased environmental contamination by heavy metals. These agencies look for techniques that provides decontamination that are not expensive and sustainable. Thus, phytoremediation is viable alternative because it is not costly. It is simple and only requires resources already available in environment such as water and sun. Also, does not impose a frequent need for monitoring the contaminated areas. Studies are required on tolerance level, which is closely related to specific pattern of physiological, biochemical and nutritional response of species to type of heavy metal. Cadmium is seventh most harmful pollutant. Studies on phytoremediation by trees is mostly restricted to some temperate species.

Moreover, there is few studies about endemic trees in Amazon region with cadmium phytoremediation potential, given that anthropic activity such as agriculture, mineration, illegal gold exploitation and disorderly growth of cities. The pollutants become more intense, contributing to release of heavy metals in soil and water resources.

In this scenario, this review studies biochemical, physiological and nutritional mechanisms of plant species, especially Swietenia macrphylla, based on previous studies showing as a potential for cadmium phytoremediator.

\section{Acknowledgements}

This work was supported by the Conselho Nacional de Desenvolvimento Científico e Tecnológico (CNPq), which granted a PhD's degree scholarship to the first author.

\section{References}

Akhtar T, Zia-ur-Rehman M, Naeem A, Nawaz R, Ali S, Murtaza G, Maqsood MA, Azhar M, Khalid H, Rizwan M (2017) Photosynthesis and growth response of maize (Zea mays L.) hybrids exposed to cadmium stress. Environ Sci Pollut R. 24: 5521-5529.

Anjum AS, Tanveer M, Hussain S, Ashraf U, Khan I, Wang L (2017) Alteration in Growth, Leaf Gas Exchange, and Photosynthetic Pigments of Maize Plants Under Combined Cadmium and Arsenic Stress. Water Air Soil Pollut. 228(13):1-12.

Anjum SA, Tanveer M, Hussain S, Shahzad B, Ashraf U, Fahad S, Bajwa AA (2016) Osmoregulation and antioxidant production in maize under combined cadmium and arsenic stress. Environ Sci Pollut Res Int. 23:11864-11875.

Antoniadis V, Levizou E, Shaheen SM, Ok YS, Sebastian A, Baum C, Prasadd MNV, Wenzelf, WW, Rinklebe J (2017) Trace elements in the soil-plant interface: Phytoavailability, translocation, and phytoremediation. Earth-Sci Rev. 171:621-645.

Arduini I, Godbold DL, Onnis A, Stefani A (1998) Heavy metals influence mineral nutrition of tree seedlings. Chemosphere 36(4-5):739-744.

Ashraf M, Foolad MR, Harris PJC (2013) Photosynthesis under stressful environments. Photosynthetica 51:163190.

Astolfi S, Zuchi S, Passera C (2005) Effect of cadmium on $\mathrm{H}+$ ATPase activity of plasma membrane vesicles isolated from roots of different S-supplied maize (Zea mays L.) plants. Plant Sci. 169:361-368. 
ATSDR (1999) Toxicological Profile for Cadmium (update). Agency for Toxic Substances and Disease Registry, Atlanta, Georgia, pp. 1-397.

Baker AJM, Brooks RR (1989) Terrestrial higher plants which hyperaccumulate elements - a review of their distribution, ecology and phytochemistry. Biorecovery 1:81-126.

Baker AJM, McGrath SP, Reeves RD, Smith JAC (2000) Metal hyperaccumulator plants: a review of the ecology and physiology of a biological resource for phytoremediation of metalpolluted soils. In: Terry N, Banuelos G (eds) Phytoremediation of contaminated soil and water, Boca Raton, FL, USA: CRC Press, pp. 85-107.

Basa B, Lattanzio G, Solti Á, Tóth B, Abadía J, Fodor F, Sárvári É (2014) Changes induced by cadmium stress and iron deficiency in the composition and organization of thylakoid complexes in sugar beet (Beta vulgaris L.). Environ Exp Bot. 101: 1-11.

Batista BL, Nigar M, Mestrot A, Rocha BA, Barbosa Júnior F, Price AH, Raab A, Feldmann J. (2014) Identification and quantification of phytochelatins in roots of rice to longterm exposure: evidence of individual role on arsenic accumulation and translocation.J Exp Bot.65(6):14671479.

Bonet A, Lelu-Walter MA, Faugeron C, Gloaguen V, Saladin G (2016) Physiological responses of the hybrid larch (Larix $\times$ eurolepis Henry) to cadmium exposure and distribution of cádmium in plantlets. Environ Sci Pollut R. 23:617-8626.

Borsari M (2011) Cadmium: Inorganic \& Coordination Chemistry. In: Encyclopedia of Inorganic and Bioinorganic Chemistry, New York: John Wiley \& Sons, Ltd.

Cao F, Cai Y, Liu L, Zhang M, He X, Zhang G, Wu F (2015) Differences in photosynthesis, yield and grain cádmium accumulation as affected by exogenous cadmium and Glutathione in the two rice genotypes. Plant Growth Regul. 75:715-723.

Cao, Z-Z, Qin, M-L, Lin, X-Y, Zhu, Z-W, Chen M-X (2018) Sulfur supply reduces cadmium uptake and translocation in rice grains (Oryza sativa L.) by enhancing iron plaque formation, cadmium chelation and vacuolar sequestration. Environ Pollut. 238:76-84.

Castro AV, de Almeida A-AF, Pirovani CP, Reis GSM, Almeida NM, Mangabeira PAO (2015) Morphological, biochemical, molecular and ultrastructural changes induced by $\mathrm{Cd}$ toxicity in seedlings of Theobroma cacao $\mathrm{L}$. Ecotox Environ Safe. 115:174-186.

Chaffei C, Pageau K, Suzuki A, Gouia H, Ghorbel MH, Masclaux-Daubresse C (2004) Cadmium Toxicity Induced Changes in Nitrogen Management in Lycopersicon esculentum Leading to a Metabolic Safeguard Through an Amino Acid Storage Strategy. Plant Cell Physiol. 45(11):1681-1693.

Chen J, Yan Z, Li X (2014) Effect of methyl jasmonate on cadmium uptake and antioxidative capacity in Kandelia obovata seedlings under cadmium stress. Ecotox Environ Safe. 104:349-356.

Chmielowska-Bak J, Gzyl J, Rucinska-Sobkowiak, R., Arasimowicz-Jelonek M, Deckert J (2014) The new insights into cadmium sensing. Front Plant Sci. 5:245

Choppala G, Saifullah Bolan N, Bibi S, Iqbal M, Rengel Z, Ok YS (2014) Cellular mechanisms in higher plants governing tolerance to cadmium toxicity. Crit Rev Plant Sci. 33(5):374-391.

Choudhury S, Panda P, Sahoo L, Panda SK (2013) Reactive oxygen species signaling in plants under abiotic stress. Plant Signal Behav. 8(4):23681.
Clemens S, Aarts M, Verbruggen, NT (2013) The key to preventing slow cadmium poisoning. Trends Plant Sci. 18:92-99.

Cobbett CS (2000) Phytochelatins and Their Roles in Heavy Metal Detoxification. Plant Physiol. 123:825-832.

Cui X, Hao H, Zhang C, He Z, Yang X (2016) Capacity and mechanisms of ammonium and cadmium sorption on different wetland-plant derived biochars. Sci Total Environ. 539:566-575.

Cunningham SD, Ow DW (1996) Promises and Prospects of Phytoremediation. Plant Physiol. 110:715-719.

Cuypers A, Karen S, Jos R, Kelly O, Els K, Tony R, Jaco V (2011) The cellular redox state as a modulator in cadmium and copper responses in Arabidopsis thaliana seedlings. J Plant Physiol. 168:(4):309-316.

Dai Z-Y, Shu, W-S, Liao B, Wan C-Y, Li J-T (2011) Intraspecific variation in cadmium tolerance and accumulation of a high-biomass tropical tree Averrhoa carambola L.: implication for phytoextraction. J Environ Monitor. 13:1723-1729.

Dat J, Vandenabeele S, Vranová E, Van Montagu, M, Inzé D, Van Breusegem, F (2000) Dual action of the active oxygen species during plant stress responses. Cell Mol Life Sci. 57(5):779-795.

de Oliveira VH, Tibbett $M$ (2018) Tolerance, toxicity and transport of $\mathrm{Cd}$ and $\mathrm{Zn}$ in Populus trichocarpa. Environ Exp Bot. 155:281-292.

Di Baccio D, Castagna, A, Tognetti R, Ranieri A, Sebastiani L (2014) Early responses to cadmium of two poplar clones that differ in stress tolerance. J Plant Physiol. 171(18):1693-1705.

Dinelli E, Lombini A (1996) Metal distributions in plants growing on copper mine spoils in Northern Apennines, Italy: the evaluation of seasonal variations. Appl Geochem. 2:375-385.

Durand TC, Hausman JF, Carpin S, Alberic P, Baillif P, Label P, Morabito D (2010) Zinc and cadmium effects on growth and ion distribution in Populus tremula $\times$ Populus alba. Biol Plantarum 54 (1):191-194.

Fan K-C, Hsi H-C, Chen C-W, Lee H-L, Hseu Z-Y (2011) Cadmium accumulation and tolerance of mahogany (Swietenia macrophylla) seedlings for phytoextraction applications. Cadmium accumulation and tolerance of mahogany (Swietenia macrophylla) seedlings for phytoextraction applications. J Environ Manage. 92:28182822.

Fontanili L, Lancilli C, Suzui N, Dendena B, Yin YG, Ferri A, Ishii S, Kawachi N, Lucchini G, Fujimaki S, Sacchi GA, Nocito FF (2016) Kinetic analysis of zinc/cadmium reciprocal competitions suggests a possible $\mathrm{Zn}$-insensitive pathway for root-to-shoot cadmium translocation in rice. Rice 9:113.

Free C, Landis RM, Grogan J, Schulze MD, Lentini M, Dünisch O (2014) Management implications of long-term tree growth and mortality trees: a modeling study of big-leaf mahogany (Swietenia macrophylla) in the Brazilian Amazon. Forest Ecol Manag. 330:46-54.

Frohne T, Diaz-Bone RA, Du Laing G, Rinklebe J (2015) Impact of systematic change of redox potential on the leaching of $\mathrm{Ba}, \mathrm{Cr}, \mathrm{Sr}$, and $\mathrm{V}$ from a riverine soil into water. J Soils Sediments 15: 623-633.

Fuksová Z, Száková J, Tlustoš P (2009) Effects of co-cropping on bioaccumulation of trace elements in Thlaspi caerulescens and Salix dasyclados. Plant Soil Environ. 55(11):461-467. 
Gallego SM, Pena LB, Barcia RA, Azpilicueta CE, lannone MF, Rosales EP, Zawoznik MS, Groppa MD, Benavides MP (2012) Unravelling cadmium toxicity and tolerance in plants: Insight into regulatory mechanisms. Environ Exp Bot 83:33-46

Gao L, Chang J, Chen R, Li H, Lu H, Tao L, Xiong J (2016) Comparison on cellular mechanisms of iron and cadmium accumulation in rice: prospects for cultivating Fe-rich but Cd-free rice. Rice 9(39):2-12.

Gautam S, Anjani K, Srivastava N (2016) In vitro evaluation of excess copper affecting seedlings and their biochemical characteristics in Carthamus tinctorius L. (variety PBNS12). Physiol Mol Biol Pla. 22(1):121-129.

Ge W, Jiao YQ, Sun BL, Qin R, Jiang WS, Liu DH (2012) Cadmium-mediated oxidative stress and ultrastructural changes in root cells of poplar cultivars. S Afr J Bot. 83:98108.

Gill SS, Tuteja N (2010) Reactive oxygen species and antioxidant machinery in abiotic stress tolerance in crop plants. Plant Physiol Bioch. 48(12):909-930.

Gomes MP, Melo Marques TCLLS, Nogueira MOG, de Castro EM, Soares AM (2011) Ecophysiological and anatomical changes due to uptake and accumulation of heavy metal in Brachiaria decumbens. Sci Agric. 68(5):566-573

Gong X, Yin L, Chen J, Gu C (2015) Overexpression of the iron transporter NtPIC1 in tobacco mediates tolerance to cadmium. Plant Cell Rep. 34(11):1963-1973

Hasan SA, Fariduddin Q, Ali B, Hayat S, Ahmad A (2009) Cadmium: Toxicity and tolerance in plants. J Environ Biol. 30(2):165-174.

Hawkes JS (1997) Heavy metals. J Chem Educ. 74:1369-1374.

He J, Li H, Luo J, Ma C, Li S, Qu L, Tyree MA (2013) transcriptomic network underlies microstructural and physiological responses to cadmium in Populus canescens. Plant Physiol. 162(1):424-439.

He J, Li H, Ma C, Zhang Y, Polle A, Rennenberg H, Luo ZB (2015) Overexpression of bacterial $\gamma$-glutamylcysteine synthetase mediates changes in cadmium influx, allocation and detoxification in poplar. New Phytol. 205(1):240-254.

Hernandez L, Cook D (1977) Modification of root plasma membrane lipid composition of cadmium-treated Pisum sativum. J Exp Bot. 48:1375-1381.

Ibrahim W, Ahmed IM, Chen X, Cao F, Zhu S, Wu F (2015) Genotypic differences in photosynthetic performance, antioxidant capacity, ultrastructure and nutrients in response to combined stress of salinity and $\mathrm{Cd}$ in cotton. Biometals 28:1063-1078.

Ivanov Yv, Kartashov Av, Ivanova Ai, Savochkin Yv And Kuznetsov Vv (2016) Effects of zinc on Scots pine (Pinus sylvestris L.) seedlings grown in hydroculture. Plant Physiol Bioch. 102:1-9.

John R, Ahmad P, Gadgil K, Sharma S, 2008. Effect of cadmium and lead on growth, biochemical parameters and uptake in Lemna polyrrhiza L. Plant Soil Environ. 54: 262270.

Kabata-Pendias A (2011) Trace Elements in Soil and Plants, 4th ed. CRC Press, Taylor \& Francis Group.

Kabata-Pendias A, Szteke B (2015) Trace elements in abiotic and biotic environments. Boca Raton: CRC Press. 425 p.

Kaur B, Singh B, Kaur N, Singh D (2018) Phytoremediation of cadmium-contaminated soil through multipurpose tree species. Agroforest Syst. 92:473-483.
Kaur N, Jhanji S (2016) Effect of soil cadmium on growth, photosynthesis and quality of Raphanus sativus, Lactuca sativa and Lactuta sativa. J Environ Biol. 37:993-997.

Khamis MH, El-Mahrook EM, Abdelgawad MA (2014) Phytoextraction potential of cádmium and lead contamination using Melia azedarach and Populus alba seelings. Afr J Biotechnol. 53:4726-4732.

Khan MD, Mei L, Ali B, Chen Y, Cheng X, Zhu SJ (2013) Cadmium-induced upregulation of lipid peroxidation and reactive oxygen species caused physiological, biochemical, and ultrastructural changes in upland cotton seedlings. Biomed Res Int. Article ID 374063, 10 pages.

Konlechner C, Türktaş M, Langer I, Vaculík M, Wenzel WW, Puschenreiter M, Hauser MT (2013) Expression of zinc and cadmium responsive genes in leaves of willow (Salix caprea L.) genotypes with different accumulation characteristics. Environ Pollut. 178:121-127

Kovtun Y, Chiu WL, Tena G, Sheen J (2000) Functional analysis of oxidative stress-activated mitogen-activated protein kinase cascade in plants. P Natl Acad Sci USA 6:2940-2945

Krupa Z (1988) Cadmium-induced changes in the composition and structure of the light-harvesting chlorophyll a/b protein complex II in radish cotyledons. Physiol Plantarum 4:518-524.

Kuzovkina YA, Knee M, Quigley MF (2004) Cadmium and Copper Uptake and Translocation in Five Willow (Salix L.) Species. Int J Phytoremediat. 6(3):269-287.

Lasat MM (2002) Phytoextraction of toxic metal: A review of biological mechanisms. J Environ Qual. 1:109-120.

Lepp NW, Madejón P (2007) Cadmium and zinc in vegetation and litter of a voluntary woodland and that has developed on contaminated sediment-derived soil. J Environ Qual. 36:1123-113.

Li H, Luo N, Li YW, Cai QY, Li HY, Mo CH, Wong MH (2017) Cadmium in rice: transport mechanisms, influencing factors, and minimizing measures. Environ Pollut. 224:622630.

Li JT, Liao B, Lan CY, Ye ZH, Baker AJM, Shu WS (2010) Cadmium Tolerance and Accumulation in Cultivars of a High-Biomass Tropical Tree (Averrhoa carambola) and Its Potential for Phytoextraction. J Environ Qual. 39:12621268.

Li N, Li R, Feng J, Zhang Z, Shen F (2015) Remediation effects of heavy metals contaminated farmland using fly ash based on bioavailability test. Transactions of the CSAE. 16:213-219.

Lima Júnior MJV, Galvão MG (2005) Mogno Swietenia macrophylla King. Informativo Técnico Redes e sementes da Amazônia 8:1-2.

Liu J, Ma J, He C, Li X, Zhang W, Xu F, Wang L (2013) Inhibition of cadmium ion uptake in rice (Oryza sativa) cells by a wall-bound form of silicon. New Phytol. 3:691699

Liu SL, Yang RJ, Ma MD, Dan F, Zhao $Y$, Jiang $P$, Wang $M H$ (2015) Effects of exogenous NO on the growth, mineral nutrient content, antioxidant system, and ATPase activities of Trifolium repens L. plants under cadmium stress. Acta Physiol Plant. 37:1-16.

Luo Z-B, Jiali H, Polle A, Rennenberg H (2016) Heavy metal accumulation and signal transduction in herbaceous and woody plants: paving the way for enhancing phytoremediation efficiency. Biotechnol Adv.34:11311148. 
Lux A, Martinka M, Vaculík M, White PJ (2011) Root responses to cadmium in the rhizosphere: a review. J Exp Bot. 62:21-37.

Lysenko EA, Klaus AA, Pshybytko NL, Kusnetsov VV (2014) Cadmium accumulation in chloroplasts and its impact on chloroplastic processes in barley and maize. Photosynth Res. 125:291-303.

Mahar A, Wang P, Ali A, Awasthi MK, Lahori AH, Wang Q, Zhang Z (2016) Challenges and opportunities in the phytoremediation of heavy metals contaminated soils: a review. Ecotox Environ Safe. 126:111-121.

Majid NM, Islam MM, Mathew L (2012) Heavy metal uptake and translocation by mangium (Acacia mangium) from sewage sludge contaminated soil. Aust J Crop Sci. 6:12281235.

Marschner H (2012) Mineral nutrition of higher plants. 3.ed London: Elsevier 643p.

Mathur S, Kalaji HM, Jajoo A (2016) Investigation of deleterious effects of chromium phytotoxicity and photosynthesis in wheat plant. Photosyntjetica 54:185192.

Matraszek R, Hawrylak-Nowak B, Chwil S, Chwil M (2016). Macroelemental composition of cadmium stressed lettuce plants grown under conditions of intensive sulphur nutrition. J Environ Manage. 180:24-34.

McLaughlin MJ, Parker DR, Clarke JM (1999) Metals and micronutrients-food safety issues. Field Crop Res. 60:143163.

Mead MN (2010) Cadmium confusion: do consumers need protection? Field Crop Res, 118:528-534.

Mendoza-Cózatl DG, Zhai Z, Jobe TO, Akmakjian GZ, Song WY, Limbo O, Russell MR, Kozlovskyy VI, Martinoia E, Vatamaniuk OK, Russell P, Schroeder JI (2010) Tonoplastlocalized Abc2 transporter mediates phytochelatin accumulation in vacuoles and confers cadmium tolerance. J Biol Chem. 285:40416-40426.

Mertens J, Vervaeke P, Meers E, Tack FM (2006) Seasonal changes of metals in willow (Salix sp.) stands for phytoremediation on dredged sediment. Environ Sci Technol. 40:1962-1968.

Mittler R (2002) Oxidative stress, antioxidants and stress tolerance. Trends Plant Sci. 7:405-410.

Mleczek M, Lukaszewski M, Kaczmarek Z, Rissmanna I, Golinski P (2009) Efficiency of selected heavy metals accumulation by Salix viminalis roots. Environ Exp Bot. 65:48-53.

Naeem A, Zafar M, Khalid H, Zia-ur-Rehman M, Ahmad Z, Ayub M.A, Qayyum MF (2019). Cadmium-Induced Imbalance in Nutrient and Water Uptake by Plants. In: Cadmium Toxicity and Tolerance in Plants, Hasanuzzaman M, Prasad MNV, Fujita M, Academic Press.

Nagajyoti PC, Lee KD, Sreekanth TVM (2010) Heavy metals, occurrence and toxicity for plants: a review. Environ Chem Lett. 8:199-216.

Negreros-Castillo P, Martínez-Salazar I, Aquino CA, Martínez NA, Mize CW (2018) Survival and growth of Swietenia macrophylla seedlings from seeds sown into slash and burn felds in Quintana Roo, Mexico. Bois For Trop. 337:1726.

Nikolić N, Zorić L, Cvetković I, Pajević S, Borišev M, Orlović S, Pilipović A (2017) Assessment of cadmium tolerance and phytoextraction ability in Young Populus deltoides L. and Populus $x$ euramericana plants through morphoanatomical and physiological responses to growth in cádmium enriched soil. iForest 10:635-644.
Nocito FF, Lancilli C, Dendena B, Lucchini G, Sacchi GA (2011) Cadmium retention in rice roots is influenced by cadmium availability, chelation and translocation. Plant Cell Environ. 34:994-1008.

Olguín EJ, Sánchez-Galván G, Pérez-Pérez T (2007) Assessment of the phytoremediation potential of Salvinia minima Baker compared to Spirodela polyrrhiza in highstrength organic wastewater. Water Air Soil Poll. 81:135147.

Oliveira VH, Tibett M (2018) Tolerance, toxicity and transport of $\mathrm{Cd}$ and $\mathrm{Zn}$ in Populus trichocarpa Environ Exp Bot. 155:281-292

Österås AH, Greger M (2006) Interactions between calcium and copper or cadmium in Norway spruce. Biol Plantarum 50:647-652.

Paiva HND, Carvalho JGD, Siqueira JO (2001). Effect of the cadmium application on nutrients content in cedro (Cedrela fissilis VELL.) seedlings. Cienc Florest. 11: 153-162.

Pereira AS, Cortez PA, De Almeida AAF, Prasad MNV, França MGC, Da Cunha M, Mangabeira PAO (2017) Morphology, ultrastructure, and element uptake in Calophyllum brasiliense Cambess (Calophyllaceae J. Agardh) seedlings under cadmium exposure. Environ Sci Pollut R. 24:1557615588.

Pereira MP, Rodrigues LCA, Corrêa FC, de Castro EM, Ribeiro VE, Pereira FJ (2016) Cadmium tolerance in Schinus molle trees is modulated by enhanced leaf anatomy and photosynthesis. Trees 30:807-814.

Pérez-Hernández I, Ochoa-Gaona S, Schroeder RHA, RiveraCruz MC, Geissen V (2013) Tolerance of Four Tropical Tree Species to Heavy Petroleum Contamination. Water Air Soil Poll. 224:1-13.

Pietrini F, lori V, Bianconi D, Mughini G, Massacci A, Zacchini M (2015) Assessment of physiological and biochemical responses, metal tolerance and accumulation in two eucalypt hybrid clones for phytoremediation of cadmiumcontaminated waters. J Environ Manage. 162:221-231.

Pitzschke A, Forzani C, Hirt H (2006) Reactive Oxygen Species Signaling

Plants. Antioxid Redox Sign. 8:9-10.

Pulford ID, Watson C (2003) Phytoremediation of heavy metal-contaminated land by trees - a review. Environ Int. 29:529-540.

Qureshi MI, D’amici GM, Fagioni M, Rinalducci S, Zolla L (2010) Iron stabilizes thylakoid protein-pigment complexes in Indian mustard during Cd-phytoremediation as revealed by BN-SDS-PAGE and ESI-MS/MS.J Plant Physiol. 167:761-770.

Rafati M, Khorasani N, Moattar F, Shirvany A, Moraghebi F, Hosseinzadeh S (2011) Phytoremediation potential of populus alba and morus alba for cadmium, chromuim and nickel absorption from polluted soil. Int J Environ Res. 5:961-970.

Rahman MF, Ghosal A, Alam MF, Kabir AH (2017) Remediation of cadmium toxicity in field peas (Pisum sativum L.) through exogenous silicon. Ecotox Environ Safe. 135:165-172.

Rehman MZ, Rizwan M, Ghafoor A, Naeem A, Ali S, Sabir M, Qayyum MF (2015) Effect of inorganic amendments for in situ stabilization of cadmium in contaminated soils and its phyto-availability to wheat and rice under rotation. Environ Sci Pollut R. 22:16897-16906.

Rivelli AR, Puschenreiter M, De Maria S (2014) Assessment of cadmium uptake and nutrient content in sunflower plants grown under Cd stress. Plant Soil Environ. 60:80-86. 
Rizwan M, Ali S, Qayyum MF, Ibrahim M, Zia-Ur-Rehman M, Abbas T, Ok YS (2016) Mechanisms of biochar-mediated alleviation of toxicity of trace elements in plants: a critical review. Environ Sci Pollut R. 23:2230-2248.

Robinson BH, Mills TM, Petit D, Fung LE, Green SR, Clothier BE (2000) Natural and induced cadmium-accumulation in poplar and willow: Implications for phytoremediation. Plant Soil 227:301-306.

Sabeen M, Mahmood Q, Irshad M, Fareed I, Khan A, Ullah F, Tabassum $S$ (2013) Cadmium phytoremediation by Arundo donax L. from contaminated soil and water. Biomed Res Int. Article ID 324830, 9 pages

Saifullah Sarwar N, Bibi S, Ahmad M, Ok YS (2014) Effectiveness of zinc application to minimize cadmium toxicity and accumulation in wheat (Triticum aestivum L.) Environ Earth Sci. 71:1663-1672.

Scandalios JG, Acevedo A, Ruzsa S (2000) Catalase gene expression in response to chronic high temperature stress in maize. Plant Sci. 156:103-110.

Sghayar S, Ferri A, Lancilli C, Lucchini G, Abruzzese A, Porrini M, Ghnaya T, Nocito FF, Abdelly C, Sacchi GA (2015) Analysis of cadmium translocation, partitioning and tolerance in six barley (Hordeum vulgare L.) cultivars as a function of thiol metabolism. Biol Fert Soils 51:311-320.

Sharma RK, Agrawal M (2005) Biological effects of heavy metals: An overview. J Environ Biol. 26:301-313.

Sharma SS, Dietz KJ, Mimura T (2016) Vacuolar compartmentalization as indispensable component of heavy metal detoxification in plants. Plant Cell Environ. 39:1112-1126.

Shi WG, Li H, Liu TX, Polle A, Peng CH, Luo ZB (2015) Exogenous abscisic acid alleviates zinc uptake and accumulation in Populus canescens exposed to excess zinc. Plant Cell Environ. 38:207-223.

Sigfridsson KG, Bernát $G$, Mamedov F, Styring $S$ (2004) Molecular interference of $\mathrm{Cd}^{2+}$ with Photosystem II. BBA-Bioenergetics 1659:19-31.

Smolders E (2001) Cadmium Uptake By Plants. Int J Occup Med Env. 14:177-183.

Soares CRFS, Accioly AMA, Marques TCLSM, Siqueira JO, Moreira FMS (2001) Content and distribution of heavy metals in roots, stems and leaves of tree seedlings in soil contaminated by zinc industry wastes. Theor Exp Plant Phys. 13:302-315.

Solti A, Gáspár L, Vági P, Záray G, Fodor F, Sárvári E (2011) $\mathrm{Cd}, \mathrm{Fe}$, and Light Sensitivity: Interrelationships in $\mathrm{Cd}$ Treated Populus 15:811-818.

Song WY, Mendoza-Cózatl DG, Lee Y, Schroeder JI, Ahn SN, Lee HS, Martinoia E (2014) Phytochelatin-metal (loid) transport into vacuoles shows different substrate preferences in barley and Arabidopsis. Plant Cell Environ. 37:1192-1201.

Souza CAS, Tucci CAF, Silva JF, Ribeiro WO (2010) Exigências nutricionais e crescimento de plantas de mogno (Swietenia macrophylla King.). Acta Amazon. 40:515-522.

Souza CR, Lima RMB, Azevedo CP, Rossi LMB (2008) Desempenho de espécies florestais para uso múltiplo na Amazônia. Sci For. 36:7-14.

Souza EP, Da Silva IDF, Ferreira LE (2013) Tolerance mechanisms the stresses for heavy metals in plants. Current Agricultural Science and Technology, 17:112.

Stoláriková-Vaculíková $M$, Romeo $S$, Minnocci $A$, Luxová $M$, Vaculík M, Lux A, Sebastiani L (2015) Anatomical, biochemical and morphological responses of poplar
Populus deltoides clone Lux to Zn excess. Environ Exp Bot. 109:235-243.

Stolt JP, Sneller FEC, Bryngelsson T, Lundborg T, Schat H (2003) Phytochelatin and cadmium accumulation in wheat. Environ Exp Bot. 49:21-28.

Takenaka C, Kobayashi M, Kanaya S (2009) Accumulation of cadmium and zinc in Evodiopanax innovans. Environ Geochem HLTH. 31:609-615.

Tauqeer HM, Ali S, Rizwan M, Ali Q, Saeed R, Iftikhar U, Abbasi GH (2016) Phytoremediation of heavy metals by Alternanthera bettzickiana: growth and physiological response. Ecotox Environ Safe. 126:138-146.

Thakur N, Sharma SS, Kishore K (2016) The Effect of Elevated $\mathrm{Ca}^{2+}$ Concentrations on Cadmium-Induced Acceleration of Leaf Senescence. J. biol chem Chron. 2:20-24.

Tran TA, Popova LP (2013) Functions and toxicity of cadmium in plants: recent advances and future prospects. Turk J Bot. 37:1-13. Unterbrunner R, Puschenreiter $\mathrm{M}$, Sommer $\mathrm{P}$, Wieshammer G, Tlustoš P, Zupan M, Wenzel WW (2007) Heavy metal accumulation in trees growing on contaminated sites in central Europe. Environ Pollut. 148:107-114.

Vaidyanathan H, Sivakumar P, Chakrabarty R, Thomas G (2003) Scavenging of reactive oxygen species in $\mathrm{NaCl}$ stressed rice (Oryza sativa L.) - differential response in salttolerant and sensitive varieties. Plant Sci. 165:1411-1418.

Varun M, D'Souza R, Pratas J, Paul MS (2011) Phytoextraction Potential of Prosopis juliflora (Sw.) DC. with Specific Reference to Lead and Cadmium. B Environ Contam Tox. 87:45-9

Veal EA, Day AM, Morgan BA (2007) Hydrogen peroxide sensing and Signaling. Mol Cell 26:1-14.

Verbruggen N, Hermans C, Schat H (2009) Molecular mechanisms of metal hyperaccumulation in plants. New Phytol. 181:759-776.

Vögeli-Lange R, Wagner GJ (1990) Subcellular Localization of Cadmium and Cadmium-Binding Peptides in Tobacco Leaves. Plant Physiol. 92:1086-1093.

Vysloužilová M, Tlustoš P, Száková J (2003) Cadmium and zinc phytoextraction potential of seven clones of Salix spp. planted on heavy metal contaminated soils. Plant Soil Environ. 49:542-547.

Wang Q, Zhang J, Zhao B, Xin X, Zhang C, Zhang H (2014) The influence of long-term fertilization on cadmium (Cd) accumulation in soil and its uptake by crops. Environ Sci Pollut R. 21:10377-10385.

Wang Y, Gu C, Bai SS, Sun Z, Zhu T, Zhu X, Grit DH, Tembrock LR (2016) Cadmium accumulation and tolerance of Lagerstroemia indica and Lagerstroemia fauriei (Lythracaeae) seedlings for phytoremediation applications. Int J Phytoremediat. 8:1104-12.

White PJ, Broadley MR (2011) Physiological limits to zinc biofortification of edible crops. Front Plant Sci. 2:1-11.

Wieshammer G, Unterbrunner R, García TB, Zivkovic MF, Puschenreiter M, Wenzel WW (2007) Phytoextraction of $\mathrm{Cd}$ and $\mathrm{Zn}$ from agricultural soils by Salix ssp. and intercropping of Salix caprea and Arabidopsis halleri. Plant Soil. 298:255-264.

Wu F, Yang W, Zhang J, Zhou L (2010) Cadmium accumulation and growth responses of a poplar (Populus deltoids $\times$ Populus nigra) in cadmium contaminated purple soil and alluvial soil. J Hazard Mater. 177:268-273. 
Xu Q, Wang C, Li S, Li B, Li Q, Chen G, Chen W, Wang F (2017) Cadmium adsorption, chelation and compartmentalization limit root-to-shoot translocation of cadmium in rice (Oryza sativa L.). Environ Sci Pollut R. 24:11319-11330.

Yoneyama T, Ishikawa S, Fujimaki S (2015) Route and regulation of zinc, cadmium, and iron transport in rice plants (Oryza sativa L.) during vegetative growth and grain filling: metal transporters, metal speciation, grain $\mathrm{Cd}$ reduction and $\mathrm{Zn}$ and Fe biofortification. Int J Mol Sci. 16:19111-19129.

Zoghlami LB, Djebali W, Abbes Z, Hediji H, Maucourt M, Moing A, Brouquisse R, Chaïbi W (2011) Metabolite modifications in Solanum lycopersicum roots and leaves under cadmium stress. Afr J Biotechnol. 10:567-579. 